\title{
Synthesis and Characterization of Silver Nanoparticles (Ag NPs) Using Sargassum sp. Extract as an Antibacterial in Woven Fabrics
}

\author{
A Wiraningtyas, Ruslan*, P A Mutmainnah \\ Department of Chemistry Education \\ STKIP Bima \\ Bima, Indonesia \\ *ruslan_kim@stkipbima.ac.id
}

\author{
E Rohaeti, K Budiasih \\ Department of Chemistry \\ Yogyakarta State University \\ Yogyakarta, Indonesia
}

\begin{abstract}
The purpose of this study was to synthesize silver nanoparticles (Ag NPs) using Sargassum sp. extract. Synthesized Ag NPs are used as antibacterial agents in woven fabrics. Sargassum sp. mixed with distilled water $(1: 4 \mathrm{w} / \mathrm{v})$ then heated in the microwave for 1 minute with various power level at $60 ; 70$ and 80. The extract obtained was dropped in an $\mathrm{AgNO}_{3}$ solution then heated in the microwave for $1 ; 3 ; 5 ; 7$ and 9 minutes and obtained colloidal silver nanoparticle. Based on analysis using UV Vis obtained that Sargassum sp. extract can be used as a bioreductor in the preparation of silver nanoparticles. The Particle Size Analyzer (PSA) was used to obtain a particle diameter with z-average is $94.8 \mathrm{~nm}$. Ag NPs applications on woven fabrics were characterized using XRD and NIR and antibacterial activity. XRD and NIR results show that Ag NPs has been deposited in woven fabrics, which is indicated by differences in spectra and diffractogram of the samples and blanks of woven fabrics. Woven fabrics deposited with Ag NPs provide antibacterial activity, both against $S$. aureus and $E$. coli bacteria.
\end{abstract}

Keywords-characterization of silver nanoparticles (Ag NPs), Sargassum sp., woven fabrics

\section{INTRODUCTION}

Sargassum sp. is a Phaeophyceae group of seaweed found in tropical areas, including Indonesia. Sargassum seaweed is widespread in Indonesia, one of which is along the coast of the island of Sumbawa - Bima. The types of Sargassum that grow in Bima include Sargassum sp., Sargassum duplicatum and Sargassum polycystum. So far, the use of Sargassum sp. in Bima it is only sold as raw material for export [1]. Sargassum $\mathrm{sp}$. contains alginate and iodine compounds which are used in the food, pharmaceutical, cosmetic and textile industries [2]. The chemical composition and pigments contained in brown seaweed are the result of photosynthesis, the number of which varies greatly depending on the type, development period and growing conditions. Sargassum sp. contains active compounds such as steroids, alkaloids, phenols, and triterpenoids which function as antibacterial, antiviral and anti-fungal [3]. In addition, these compounds can act as reducing agents because they have a strong tendency to reduce metals. Bioreductor is a reduction method by utilizing biological materials, both microorganisms and plants, as reducing agents for metal ions. The ability to chelate and reduce metals in phenol compounds is due to the high nucleophilic character of aromatic rings [4]. Seaweed Sargassum sp. has more capabilities than other natural materials as a bioreductor. The use of bioreductors in the synthesis of nanoparticles is known as the biosynthetic method [5].

Nanoparticles have been widely used in various fields such as health, cosmetics, food, and the environment [6]. One of the nanoparticles that have been widely developed is silver nanoparticles because they have properties as antibacterial agents [7]. The shape and size of silver nanoparticles are very important in determining their optical, electrical, magnetic, catalyst and antimicrobial properties [8]. The smaller the particle size the greater the antimicrobial effect [9]. In this study, silver nanoparticles were synthesized using extracts of Sargassum sp. Extraction of dye from seaweed Sargassum sp. microwave method is used so that extraction process can be short.

\section{EXPERIMENTAL SECTION}

\section{A. Extraction of Bioreductor}

Sargassum sp. powder of mixed with distilled water at a ratio of $1: 4(\mathrm{w} / \mathrm{v})$ then heated in the microwave for 1 minute at power level 60; 70 and 80 . The mixture obtained was then filtered until the extract of Sargassum sp. [10].

\section{B. Preparation of Silver Nanoparticles (Ag NPs)}

The synthesis of silver nanoparticles was carried out by mixing $90 \mathrm{~mL}$ of $1 \times 10-3 \mathrm{M} \mathrm{AgNO} 3$ solution with $10 \mathrm{~mL}$ of extract of Sargassum sp. then heated in the microwave for $1 ; 3$; 5; 7 and 9 minutes. The mixture obtained was then analyzed using a UV Vis and PSA spectrophotometer. 


\section{Application on Woven Fabrics}

The woven fabric is cut to a size of $10 \mathrm{~cm} \times 10 \mathrm{~cm}$. Then dip it in colloidal silver nanoparticles then stirred using a shaker at $150 \mathrm{rpm}$ for 24 hours and dried at $30^{\circ} \mathrm{C}$ [11].

\section{Antibacterial Activity}

The test was carried out by placing a woven cloth coated with nanoparticles and a blank woven cloth that was cut round over a culture of Staphylococcus aureus and Escherichia coli bacteria. Clear zone measurements were carried out after 24 hours of incubation time for bacteria and carried out for 48 hours of incubation time [11].

\section{DISCUSSION}

This research was conducted to synthesize silver nanoparticles (Ag NPs) using a bioreductor from the extract of seaweed Sargassum sp. The synthesis method using reducing agents from natural materials is known as biosynthesis. The dye extraction process and biosynthesis of silver nanoparticles in this study were carried out with the help of microwave radiation. In the process of extracting dye from the powder of Sargassum sp. done using the microwave for 1 minute. The use of microwave in the extraction process is due to the energy in the microwave extraction process directly to the specific target sample and in a specific way, so that no heat is lost to the environment, because the heating process takes place in a closed system [12]. The unique heating mechanism can significantly reduce the time required for the extraction process [13]. Heating using microwave involves three times the conversion of energy, namely electrical energy into electromagnetic energy, then kinetic energy and then into heat energy [14].

The heating process uses a microwave starting from the outside of the surface then conduction into the sample so that the inside of the sample will also be heated. However, the higher the microwave power level used in the extraction process will cause a decrease in the absorbance value of the extract. This is because the high heating causes a change in the structure of the compound and the evaporation of the bioactive compounds in the extract of Sargassum sp. Graph of the absorbance measurement results of Sargassum sp. on the variation of microwave power level as shown in Figure 1. Based on the UV Vis graph in Figure 1 shows that the extraction process of Sargassum sp. produce an extract with optimum absorbance at level 60.

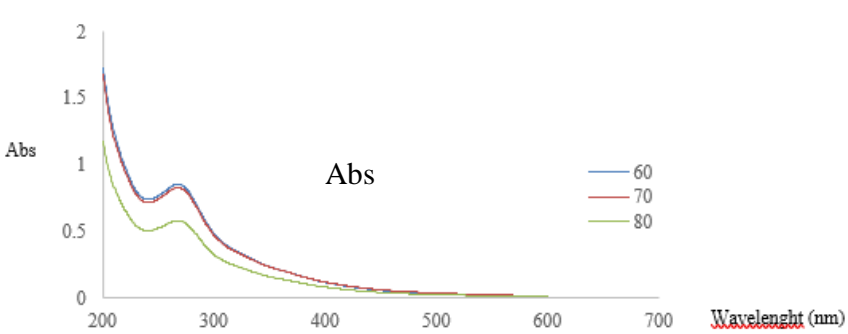

Fig. 1. UV Vis graph of Sargassum sp. in power level variations.

In the extraction process, the extract of Sargassum sp. brown. The extract obtained was then mixed with 1 x 10-3 M AgNO3 solution as a precursor. In the biosynthesis process of silver nanoparticles, microwaves are also used to speed up the synthesis process. The synthesis process is carried out at a power level of 60 with a variation of heating time. The result of the synthesis is colloidal silver and a white precipitate is formed. The results of the characterization of colloidal silver using a UV Vis spectrophotometer as shown in Figure 2 below.

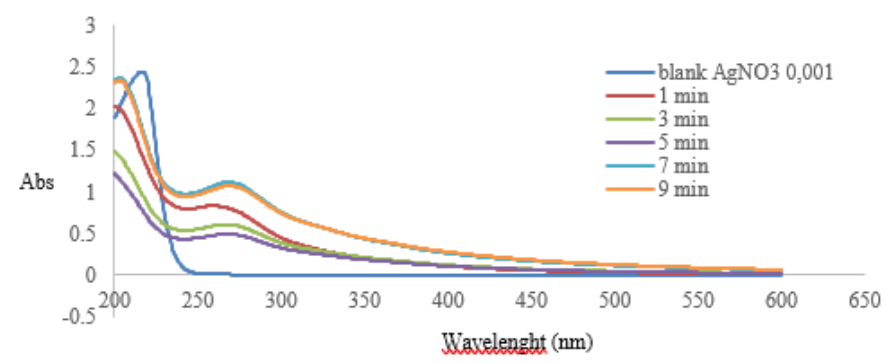

Fig. 2. UV Vis Graph of Silver Nanoparticles on heating time variations.

Based on the graph in Figure 2 shows that the UV Vis graph of the precursor for the AgNO3 solution produces a peak at a wavelength of $216 \mathrm{~nm}$. Meanwhile, the UV Vis graph of the colloidal silver nanoparticles experienced a peak shift at a wavelength of $268 \mathrm{~nm}$. The shift in the absorbance peak indicates that the colloid has formed $\mathrm{Ag}$ nanoparticles of varying sizes. In addition, the shift in the absorption peak was caused by the bonding between silver particles and the $\mathrm{OH}$ group in the extract of Sargassum sp. thus increasing the amount of energy required for electron excitation [15]. Biosynthesis of silver nanoparticles was carried out by varying the synthesis time. Based on the UV Vis graph in Figure 2, it is found that the optimum product for silver nanoparticles is obtained for 7 minutes of synthesis.

Particle size greatly affects the properties and performance of a material. The smaller the size of a particle, the better its properties and performance. The silver nanoparticles produced in this study were measured using Particle Size Analysis (PSA). The data from the measurement of silver particle diameter are as shown in Figure 3. Based on the graph in Figure 3, the size of the silver nanoparticles produced by the synthesis has a diameter that varies from $39.58-279 \mathrm{~nm}$. While the average size of the particle diameter is $94.8 \mathrm{~nm}$. 


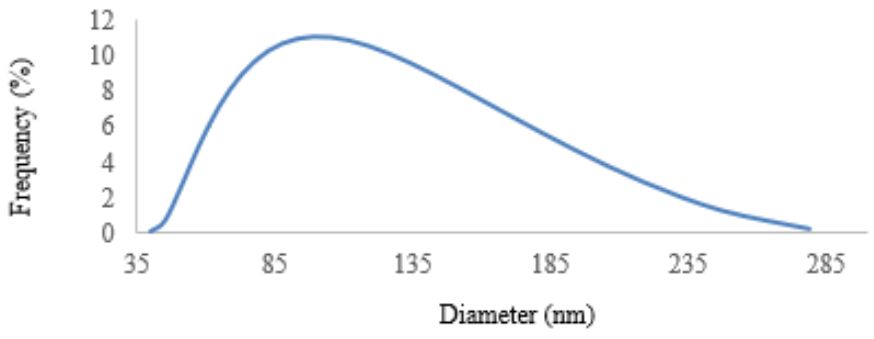

Fig. 3. Particle distribution of Ag NPs.

Analysis of woven fabrics using Near Infrared (NIR) radiation was carried out to detect the presence of Ag NPs deposited on woven fabrics. Figure 4 shows a diagram of the NIR radiation absorbance spectra on a woven cloth. Based on the spectra in Figure 4, that woven fabrics deposited with $\mathrm{Ag}$ NPs have a higher absorbance spectrum than woven fabrics without modification (blank). The presence of Ag NPs on the surface of the woven cloth can absorb more wave radiation than the blank woven fabric with a larger particle size on the surface. NIR radiation hitting woven fabrics has little energy and only penetrates about $1 \mathrm{~mm}$ of the fabric surface, depending on the fabric composition. The particle size of the sample affects the spread of NIR radiation as it passes through the sample. Large particles cannot scatter NIR radiation as much as small particles. The more radiation that is absorbed can provide a high absorbance value.

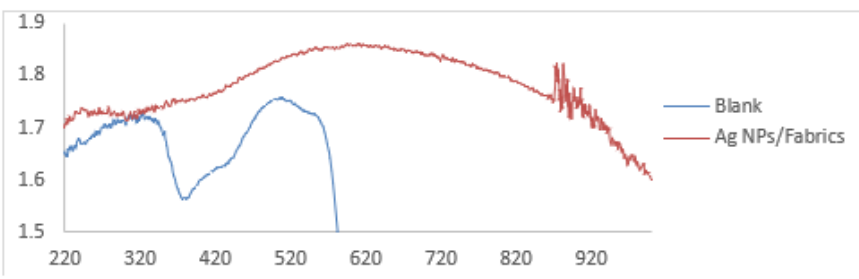

Fig. 4. UV Vis NIR graph of Ag NPs coated fabrics.

The results of the characterization of woven fabrics using XRD are as shown in Figure 5. Based on the diffraction pattern, it is found that the woven fabrics that are neither coated nor coated with Ag NPs are amorphous. The blank cloth diffractogram obtained the main peak at $2 \theta=10.58^{\circ} ; 2 \theta=$ $12.04^{\circ} ; 2 \theta=20.36^{\circ}$ and $2=21.84^{\circ}$. These peaks show the characteristics of cotton cloth. The diffractogram of Ag NPs coated cloth, high intensity peaks were obtained at $2 \theta=32.7^{\circ}$ and $2 \theta=46.94^{\circ}$. The peaks that appear on both diffractograms indicate the presence of peaks of Ag NPs embedded in the woven fabric.

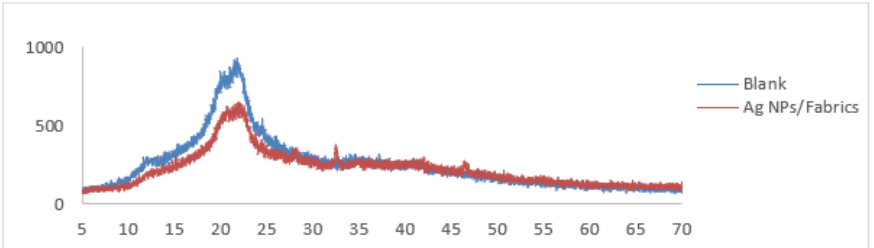

Fig. 5. The diffractogram of a woven fabric.
Clear zone measurements were carried out for 48 hours of incubation. The data from the observation of the clear zone in the sample are presented in table 1.

TABLE I. DIAMETER OF THE CLEAR ZONE OF WOVEN FABRIC SAMPLES AGAINST E. COLI AND S. AUREUS

\begin{tabular}{|l|l|l|}
\hline Hours & E. coli & S. aureus \\
\hline 0 & 0.0 & 0.0 \\
\hline 3 & 0.2 & 0.1 \\
\hline 6 & 3.0 & 1.5 \\
\hline 9 & 3.9 & 2.2 \\
\hline 12 & 1.7 & 2.7 \\
\hline 15 & 1.8 & 1.8 \\
\hline 18 & 0.3 & 1.0 \\
\hline 21 & 0.3 & 1.1 \\
\hline 24 & 0.0 & 0.7 \\
\hline 42 & 0.0 & 0.5 \\
\hline 48 & 0.0 & 0.0 \\
\hline
\end{tabular}

Based on the observation of the clear zone diameter of the woven cloth samples against $E$. coli and $S$. aureus bacteria which are presented in table 1 , a graph of the relationship between time and the diameter of the clear zone can be made as shown in Fig. 6.

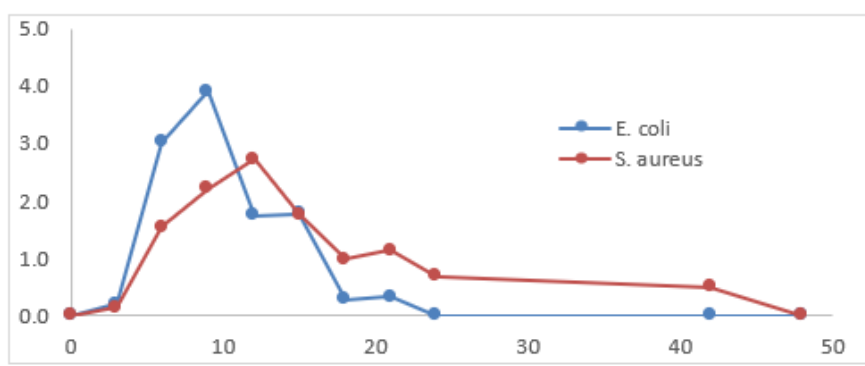

Fig. 6. Diameter graph of woven fabrics clear zone against bacteria.

Based on the tables and figures, it shows that the clear zone begins to form at 3 hours of incubation. At that time the bacteria have entered the multiplication phase so that the antibacterial activity of the sample can be seen. It can also be seen that the samples have different antibacterial activity, as seen from the clear zone diameter data obtained. In this study, AgNPs were used to increase the antibacterial properties of woven fabric samples. This is because AgNPs have antimicrobial properties and are able to kill all pathogenic microorganisms. Based on the results of this study, the Ag NPs deposited cloth samples provide antibacterial activity, both against $E$. coli and $S$. aureus bacteria.

\section{CONCLUSION}

Silver nanoparticles (Ag NPs) can be synthesized using Sargassum sp. extracts. The extraction and synthesis processes can be carried out with the help of microwave. Absorbance of the extract of Sargassum sp. The resulting optimum power level was 60. Synthesis of Ag NPs at the variation of synthesis time obtained the optimum conditions for 7 minutes. The size of the synthesized Ag NPs varied in diameter from 39.58 to 
$279 \mathrm{~nm}$ with an average particle diameter of $94.8 \mathrm{~nm}$. AgNPs applications on woven fabrics were characterized using XRD and NIR and antibacterial activity. XRD and NIR results show that Ag NPs has been deposited in woven fabrics, which is indicated by differences in spectra and diffractogram of the samples and blanks of woven fabrics. Woven fabrics deposited with Ag NPs provide antibacterial activity, both against $S$. aureus and E. coli bacteria.

\section{ACKNOWLEDGMENTS}

The authors thank for the financial support from Ministry of Research, Technology/BRIN Indonesia.

\section{REFERENCES}

[1] R. Ruslan, A. Amir, and W. Agrippina, "Extraction of Sodium Alginate from Sargassum Sp. Using Microwave-Assisted Extraction (MAE).," J. Pure Appl. Chem. Res., vol. 8, no. 1, pp. 23-30, 2019.

[2] A. Michalak, "Phenolic Compounds and Their Antioxidant Activity in Plants Growing under Heavy Metal Stress.," Polish J. Environ. Stud., vol. 15 , no. $4,2006$.

[3] N. Abdel-raouf, N.M. Al-enazi, I. Borie, M. Ibraheem, R. Mohammed, and M. Mohammed, "Saudi Journal of Biological Sciences Biosynthesis of Silver Nanoparticles by Using of the Marine Brown Alga Padina Pavonia and Their Characterization," Saudi J. Biol. Sci., pp. 1-9, 2018.

[4] M. Vanaja, K. Paulkumar, G. Gnanajobitha, S. Rajeshkumar, C. Malarkodi, and G. Annadurai, "Herbal Plant Synthesis of Antibacterial Silver Nanoparticles by Solanum Trilobatum and Its Characterization," Int. J. Met., vol. 2014, 2014.

[5] Y.-X. Yao, H.-B. Li, J.-Y. Liu, X.-L. Tan, J.-G. Yu, and Z.-G. Peng, "Removal and Adsorption of P-Nitrophenol from Aqueous Solutions Using Carbon Nanotubes and Their Composites," J. Nanomater., vol. 2014, 2014.
[6] P. Jegadeeswaran, R. Shivaraj, and R. Venckatesh, "Green Synthesis of Silver Nanoparticles from Extract of Padina Tetrastromatica Leaf," Dig. J. Nanomater. Biostructures, vol. 7, no. 3, pp. 991-998, 2012.

[7] K. Saravanakumar and M.-H. Wang, "Trichoderma Based Synthesis of Anti-Pathogenic Silver Nanoparticles and Their Characterization, Antioxidant and Cytotoxicity Properties," Microb. Pathog., vol. 114, pp. 269-273, 2018.

[8] R.R.R. Kannan, W.A. Stirk, and J. Van Staden, "Synthesis of Silver Nanoparticles Using the Seaweed Codium Capitatum PC Silva (Chlorophyceae)," South African J. Bot., vol. 86, pp. 1-4, 2013.

[9] T.E. Motaung, L.Z. Linganiso, and S.M. Mohomane, "BIOCOMPOSITES BASED ON BIOMASS," Prop. Perform. Appl., p. 147.

[10] R. Ruslan, "Biosintesis Nanopartikel Fe Dari Pasir Besi Menggunakan Ekstrak Kulit Bawang Merah,” J. REDOKS (Jurnal Pendidik. Kim. dan Ilmu Kim., vol. 2, no. 2, pp. 35-42, 2019.

[11] E. Rohaeti and A. Rakhmawati, "The Hydrophobicity and the Antibacterial Activity of Polyester Modified With Silver Nanoparticle and Hexadecyltrimethoxysilane," Molekul, vol. 12, no. 1, pp. 78-87, 2017.

[12] A. Amir, A. Wiraningtyas, R. Ruslan, and N. Annafi, "Perbandingan Metode Ekstraksi Natrium Alginat: Metode Konvensional Dan Microwave Assisted Extraction (MAE)," Chempublish J., vol. 1, no. 2, pp. 7-13, 2016.

[13] T. Jain, V. Jain, R. Pandey, A. Vyas, and S.S. Shukla, "Microwave Assisted Extraction for Phytoconstituents-An Overview," Asian J. Res. Chem., vol. 2, no. 1, pp. 19-25, 2009.

[14] V. Mandal, Y. Mohan, and S. Hemalatha, "Microwave Assisted Extraction - an Innovative and Promising Extraction Tool for Medicinal Plant Research,” Pharmacogn. Rev., vol. 1, no. 1, pp. 7-18, 2007.

[15] Z. Salari, F. Danafar, S. Dabaghi, and S.A. Ataei, "Sustainable Synthesis of Silver Nanoparticles Using Macroalgae Spirogyra Varians and Analysis of Their Antibacterial Activity," J. Saudi Chem. Soc., vol. 20, no. 4, pp. 459-464, 2016. 